\title{
NEW SUPERTRIBES, HELIANTHODAE AND SENECIONODAE, FOR THE SUBFAMILY ASTEROIDEAE (ASTERACEAE)
}

\section{Harold Robinson}

Department of Botany; National Museum of Natural History, P.O. Box

37012, Smithsonian Institution, Washington DC, 20013-7012.

\section{ABSTRACT}

Three supertribes are recognized in the subfamily Asteroideae of the Asteraceae; two new supertribes, Helianthodae and Senecionodae, and the typical supertribe Asterodae.

KEY WORDS: Subfamily Asteroideae, supertribes, Asterodae, Helianthodae, Senecionodae.

DNA studies in the Asteraceae have reached the point where the main elements of the family have been mostly resolved. Two papers (Panero and Funk 2002; Baldwin et al. 2002) have already made taxonomic changes needed to accommodate some of the new findings. The present paper is restricted to providing needed new major taxonomic groupings for the subfamily Asteroideae. The main divisions in the subfamily are presently the tribes, but these are obviously grouped into larger units below the subfamily level. There has been some discussion of merging well-established tribes, such as the Eupatorieae and Heliantheae, to represent these larger groupings. Reducing the number of hierarchical strata in the taxonomy of a large complex family such as the Asteraceae is not considered here as a viable option. The solution offered here is to adopt a scarcely used but functional category to increase the number of strata in the classification by adding the supertribe. The threesupertribe system for the subfamily Asteroideae adopted here includes the typical supertribe Asterodae and the new supertribes Helianthodae and Senecionodae. 
The adoption of the supertribal classification has involved a search for the proper ending to be used. The supertribe rank is one of those that might be expected from provisions in the International Code of Botanical Nomenclature, but it is not found there and the rank has rarely been used in practice. Thanks to Rob Soreng, working in the Smithsonian Grass Laboratory, three examples of supertribes in the grasses can be cited. These are cited in the Catalogue of New World Grasses (Soreng et al. 2003). They are:

Supertribe Stipodae L. Liou, Acta Phytotax. Sin. 18(3):324-325 (1980), type Stipa L.

Supertribe Poodae L. Liou, Acta Phytotax. Sin. 18(3):324 (1980), type Poa L.

Supertribe Triticodae T.D. Macfarl. \& L. Watson, Taxon 31(2):192 (1982), type Triticum L.

These previous examples of the use of the supertribe rank are helpful as a precedent, and as a source for a previously established ending for the category, -odae.

The general pattern of DNA results can be seen in Panero and Funk (2002) and Funk et al. (2004, in press). The groups here described as the Helianthodae, Senecionodae, and typical subtribe Asterodae all appear as strictly monophyletic in that study. This is achieved by placing the Inuleae in the supertribe Helianthodae in spite some features that are closer to the Asterodae. The limits of the new groups seem clearly defined in the DNA results, but supporting structural characters are not as consistent. The best character for the Senecionodae remains the specialized involucre and the best character for the Helianthodae is the presence of phytomelanin in the achene walls although this has important exceptions as indicated below.

The supertribes and the tribes they include are as follow: 
Supertribe Asterodae: type Aster L. Achene walls without phytomelanin, usually with raphides; involucral bracts not subvalvate, mostly gradate, with margins often broadly scarious; anthers with or without long tails; style tips blunt to triangular or truncate; receptacles rarely paleate.

Included are the following tribes.

Anthemideae Cass., J. Phys. Chim. Hist. Nat. Arts 88:192 (1819).

Astereae Cass., J. Phys. Chim. Hist. Nat. Arts 88:195 (1819) (typical).

Calendulae Cass., J. Phys. Chim. Hist. Nat. Arts 88:161 (1819).

Gnaphalieae Cass. ex Lecoq \& Juillet, Dict. Rais. Term. Bot.: 296. 1831.

Helianthodae H. Rob., supertribus nov., type Helianthus L. Achaenia in parietibus plerumque phytomelaninifera rarius raphidifera; bracteae involucri non subvalvatae saepe gradatae vel herbaceae; receptacula saepe paleata; antherae non vel longe caudatae; styli apice non truncati non triangulares.

The primary characteristic, phytomelanin in the achene walls, is unique in the subfamily Asteroideae to the supertribe Helianthodae; it seems to be lacking through loss of the character in included groups such as Marshallia Schreb., the Gaillardiinae of the Helenieae, and Sartoria R.M.King \& H. Rob. of the Eupatorieae. The Inuleae, which have a more basal position in the DNA results may be showing an ancestral lack of phytomelanin.

Included are the following tribes.

Athroismeae J.L. Panero, Proc. Biol. Soc. Wash. 115(4):917 (2002). The tribe probably also includes the genera of the Anisopappus Hook. \& Arn. group, in spite of the more prismatic achenes lacking phytomelanin in the latter. 
Coreopsideae (Less.) B.L.Turner \& A.M.Powell, in V.H. Heywood, J.B. Harborne \& B.L.Turner, eds., Biology and Chemistry of the Compositae 2:724 (1977); based on subtribe Coreopsidinae Less., Linnaea 5:153 (1830).

Eupatorieae Cass., J. Phys. Chim. Hist. Nat. Arts 88:202 (1819).

Helenieae Lindl. in Loud., Encycl. Pl.: 1074. 1829.

Heliantheae Cass., J. Phys. Chim. Hist. Nat. Arts 88:180 (1819).

Inuleae Cass., J. Phys. Chim. Hist. Nat. Arts 88:193 (1819). Including Plucheeae (Benth.) Anderb.,

Canad. J. Bot. 67:2293 (1989); based on subtribe Plucheinae Benth. in Benth. \& Hook.f., Gen. P1. 2:180 (1873)(Plucheineae).

Tageteae Cass., J. Phys. Chim. Hist. Nat. Arts 88:162 (1819).

Senecionodae H. Rob., supertribus nov., type Senecio L. Achaenia in parietibus non phytomelaninifera; bracteae involucri subvalvatae non gradatae plerumque inferne calyculatae; antherae non vel breviter caudatae; styli plerumque truncati vel penicillati rarius triangulares; receptacula non paleata.

The achene walls examined of the Senecioneae lack raphides, but the raphides in the ovules show through and often seem to be in the wall (Janovec \& Robinson 1997).

The supertribe includes only the single following tribe.

Senecioneae Cass., J. Phys. Chim. Hist. Nat. Arts 88:196 (1819).

\section{ACKNOWLEDGMENTS}

I thank Vicki A. Funk, Marjorie Knowles, Guy L. Nesom, and James Reveal for reviewing the paper and making helpful suggestions. 


\section{LITERATURE CITED}

Baldwin, B. G., B. L. Wessa, and J. L. Panero. 2002. Nuclear rDNA evidence for major lineages of Helenioid Heliantheae (Compositae). Syst. Bot. 27:161-198.

Funk, V. A., R. J. Bayer, S. Keeley, R. Chan, L. Watson, B. Gemeinholzer, E. Schilling, J. L. Panero, B. G. Baldwin, N. T. Garcia-Jacas, A. Susanna and R. K. Jansen. 2004. Everywhere but Antarctica: Using a supertree to understand the diversity and distribution of the Compositae. In: Friis, I. \& Balslev, H. (eds.) Proceedings of a Symposium on Plant Diversity and Complexity Patterns - Local, Regional and Global Dimensions. The Royal Danish Academy of Sciences and Letters, Copenhagen. Pp. 000000. (page proofs expected in August 04)

Janovec, J. P. and H. Robinson. 1997. Charadranaetes, a new genus of the Senecioneae (Asteraceae) from Costa Rica. Novon 7(2):162168.

Panero, J. L. and V. A. Funk. 2002. Toward a phylogenetic subfamilial classification for the Compositae (Asteraceae). Proc. Biol. Soc. Wash. 115(4):909-922.

Soreng, R. J., P. M. Peterson, G. Davidse, E. J. Judziewicz, F. O. Zuloaga, T. S. Filgueiras and O. Morrone. 2003. Catalogue of New World Grasses (Poaceae): IV. Subfamily Pooideae. Contr. U. S. Natl. Herb. 48:1-730. 


\section{$2 \mathrm{BHL}$ Biodiversity Heritage Library}

Robinson, Harold Ernest. 2004. "New supertribes, Helianthodae and Senecionodae, for the subfamily Asteroideae (Asteraceae)." Phytologia 86, 116-120. https://doi.org/10.5962/bhl.part.28428.

View This Item Online: https://www.biodiversitylibrary.org/item/46799

DOI: https://doi.org/10.5962/bhl.part.28428

Permalink: https://www.biodiversitylibrary.org/partpdf/28428

\section{Holding Institution}

New York Botanical Garden, LuEsther T. Mertz Library

\section{Sponsored by}

The LuEsther T Mertz Library, the New York Botanical Garden

\section{Copyright \& Reuse}

Copyright Status: In copyright. Digitized with the permission of the rights holder.

Rights Holder: Phytologia

License: http://creativecommons.org/licenses/by-nc-sa/3.0/

Rights: https://biodiversitylibrary.org/permissions

This document was created from content at the Biodiversity Heritage Library, the world's largest open access digital library for biodiversity literature and archives. Visit BHL at https://www.biodiversitylibrary.org. 